\title{
W zniewoleniu szczęśliwi. Raz jeszcze o Zniewolonym umyśle Miłosza
}

Marek Zaleski

TEKSTY DRUGIE 2018, NR 4, S. 259-273

DOI: 10.18318/td.2018.4.16

$Z$ niewolony umyst, książka, której Miłosz nie lubił, uważał ją bowiem za wymuszoną na sobie przez okoliczności, miał na Zachodzie wielu zdeklarowanych admiratorów: Karla Jaspersa, Alberta Einsteina, Benedetto Croce, Alberta Camusa, Tomasza Mertona, Dwighta McDonalda, by wymienić jedynie najgłośniejsze nazwiska. Ma ich i dzisiaj. W przekonaniu Tony'ego Judta, jest to „najbardziej wnikliwa i ponadczasowa opowieść o uwiedzeniu intelektualistów przez stalinizm, i w sensie bardziej ogólnym, o tym, jak inteligencja poddaje się urokowi władzy totalitarnej"'. Znamienne jest użycie przez Judta niemal sześćdziesiąt lat po ukazaniu się książki Miłosza słów „uwiedzenie" i „urok” do opisu zdarzeń zachodzących w realiach, które - zdawałoby się - bardziej usprawiedliwiałyby użycie słów takich jak „zniewolenie" $i$ „przemoc". Zabieg ten wprowadza interpretacyjny - i czy aby nie

1 T. Judt Captive minds, "The New York Review of Books" 30 września 2010. Cyt. za T. Judt Zniewolone umysły dawniej i dziś, przeł. K. Witakowska, ,"Gazeta Wyborcza" z 06.09.2010. 
nadrzędny? - kontekst, który w wyjaśnianiu dokonywanych wówczas wyborów dziś wydaje się w oczywisty sposób istotny, a który wówczas, dla współczesnych Miłosza, gdy ukazała się jego książka a i jeszcze w wiele lat potem, uważany był za bałamutny, a w najlepszym razie znakomicie drugorzędny. Słowa „urok" i „uwiedzenie” jako mechanizm wyjaśniania nakierowują nas na erotyczną, a w języku psychoanalizy, na libidalną ekonomię podmiotu. Miłosz w swojej książce oczywiście nie posługuje się językiem psychoanalizy: nie jest to język całkowicie mu obcy, ale nie uważa go za pożyteczne narzędzie w opisie politycznych, koniec końców, zachowań ludzi na wschodzie Europy, poddanym nowej despotycznej władzy ${ }^{2}$. Można to uznać za następstwo wychowania w katolickiej kulturze umysłowej, w której psychoanaliza nie tylko nigdy nie cieszyła się uznaniem, wręcz przeciwnie, znalazła się na cenzurowanym. W przekonaniu Miłosza w roku 1953 (ale i potem) znajomość natury ludzkiej wyniesiona z lektur teologów, filozofów i antropologów wydaje się wystarczającym wyposażeniem, by stawiać diagnozy. Niechęć Miłosza do psychoanalizy zasługuje skądinąd na osobne studium. Tak czy inaczej i dziś - po latach, imponuje przenikliwość Miłosza: odsłaniany przez niego mechanizm akcesu intelektualistów ciągle zasługuje na uwagę, ale nie będzie przesadą stwierdzenie, że dziś to psychoanaliza właśnie nazywa go i nadaje mu pełniejsze znaczenie. Mimo że Miłosz dystansuje się od niej, daleki jest od uproszczeń i mimowiednie jego ogląd pozostaje bardzo zbliżony i - pozwólmy tu sobie na żartobliwą i zaprawioną anachronizmem spekulację - gdyby jego książka została napisana w tandemie z psychoanalitykiem, jak w wiele lat poźniej książka Testimony: Crises of Witnessing in Literature Psychoanalysis and History Shoshany Felman, napisana z Dori Laubem, zyskalibyśmy może jeszcze więcej. Kategorie, jakimi posługuje się Miłosz, opisując zniewolenie

2 "Obywatel demokracji ludowych wolny jest od newrozy, która przybiera tak rozliczne formy w krajach kapitalistycznych. Na Zachodzie człowiek stoi wobec społeczeństwa, które uważa podświadomie za coś nie związanego ze sobą. Gra swoją osobistą grę; społeczeństwo wyznacza mu pewne granice, których nie powinien przekroczyć; w zamian za to otrzymuje on gwarancję, że nikt nie będzie zbytnio się mieszał do jego sfery działania. Jeżeli przegrywa, mówi się, że sam jest sobie winien. Niech pomaga mu psychoanaliza. Na Wschodzie nie ma przeciwstawienia ani granicy pomiędzy człowiekiem i społeczeństwem. Jego przegrana czy wygrana jest sprawą publiczną. Nigdy nie jest sam. Jeżeli ginie, ginie nie z powodu obojętności otoczenia: dlatego, że niestety otoczenie obserwuje go z nadmierną uwagą. Newrozy pospolite na Zachodzie są, jak wiadomo, przede wszystkim wynikiem samotności człowieka, a więc w demokracjach ludowych psychoanalitycy - nawet założywszy, że pozwolono by im praktykować - nie zarobiliby ani grosza", Cz. Milosz, Zniewolony umysł, w: tegoż Dzieła zebrane, Wydawnictwo Literackie, Kraków 1999, s. 247. Dalej podaję w nawiasach cytaty za tym wydaniem dzieła Miłosza. 
stające się dobrowolnym akcesem, a więc swego rodzaju samozniewoleniem, prowadzą go do wniosku, że zaangażowanie po stronie brutalnej władzy okazuje się kwestią - jak zaznacza - „dużo poważniejszą niż sprawa przemocy” (s. 27). Wszelako w latach 50. (a i jeszcze wiele lat później) książka Miłosza wielu czytelnikom (Giedroyc, Bobkowski, Herling) jawiła się jako wykoncypowana, „świetnie napisana, lecz błędna «wydumana» za biurkiem”3 po to, by usprawiedliwić nie tyle zaangażowanie autora, co jego kilkuletni fakt współpracy z reżimem w placówkach dyplomatycznych komunistycznego państwa. Liczył się przede wszystkim kontekst, który kwestie poruszane przez Miłosza czynił funcją przemocy politycznej (a więc rozmaitych postaci stosowanego terroru i strachu) oraz przemocy ekonomicznej (zagrożenie codziennej egzystencji w sytuacji szybko rosnącego monopolu państwa jako pracodawcy). Części krytyków, zwłaszcza na emigracji, konstrukcje użyte przez Miłosza do charakterystyki pisanej wielką literą "Metody” koncesjonowanej jako jedyna słuszna forma myślenia, czyli do opisu dialektyki marsistowskiej i materializmu historycznego wydały się nazbyt wysofistyfikowane, a sama Metoda demonizowana jako przemożne intelektualne narzędzie, tymczasem miała przysłonić wstyd za czynny w tym wszystkim oportunizm a i słabość charakteru - również samego autora książki. Tymczasem nieprawdą jest, że Miłosz lekceważył albo i pomijał całkowicie polityczną przemoc skłaniającą do konformizmu. Na kartach swego eseju o strachu pisze wielokrotnie, przyjmując za oczywiste, że narzędzia indoktrynacji w krzewieniu komunistycznej „Nowej Wiary” nie okazałyby się skuteczne, gdyby nie strach właśnie. Ten akurat afekt na kartach książki Miłosza jest wszechobecny, pojawia się pod różnymi postaciami i znajduje wielorakie eksplikacje. Jeśli jednak Zniewolony umyst odniósł międzynarodowy sukces i został uznany za diagnozę sytuacji zniewolenia wykraczającą poza opisywany historyczny przypadek, to stało się tak co najmniej z dwóch powodów.

Po pierwsze, dla Miłosza kwestia akcesu intelektualistów do niedemokratycznego, komunistycznego ustroju pozostaje bardziej etyczna aniżeli polityczna: rozważa on przede wszystkim emocje i racje czynne w dokonywaniu codziennych wyborów; dopiero potem zyskują one kwalifikację polityczną bądź moralną. „Strach jest [...] cementem społeczeństw znanym od dawna” (s. 266) - pisze Miłosz, i trudno się z nim nie zgodzić, o czym za chwilę. I nie mniej istotne jest właśnie to, że oprócz oczywistego strachu przed represjami

3 G. Herling-Grudziński Dziennik pisany nocq, Instytut Literacki, Paryż 1980, s. 179 (zapis Z 11 czerwca 1976 roku). 
ze strony władzy Miłosz w swoim dziele przedmiotem uwagi czyni także "strach przed myśleniem na własny rachunek" (s. 31). Ujmując rzecz inaczej, przedmiotem uwagi czyni konformizm, który stanowi uniwersalną siłę w regulowaniu stosunków między jednostką a władzą, podmiotem a władzą symboliczną, upostaciowaną we „wzniosłych obiektach ideologii” (copyright Slavoj Žižek), które komunistyczna "Nowa Wiara” powołuje do istnienia. Roszczenia władzy zdaniem Miłosza - co trzeba tu przypomnieć - są akurat wsparte silnym argumentem kryptoteologicznym, tzn. wsparte heglowsko interpretowanym wywodem o dziejowej konieczności. Autor Zniewolonego umystu podkreśla: krytykom i oponentom zamykano usta, ale nawet kiedy przemawiali, i im samym często ich słowa wydawały się jedynie bezsilną negacją, jałową retoryką: „Nie zwycięża się Mesjasza argumentami rozsądnych ludzi, z których ust wychodzą słowa, a nie miecz z płomienia" - zaznacza (s. 64).

Po drugie, Miłosz zwraca uwagę na nieoczywistość kryjącą się w zniewoleniu - nieoczywistość, która przy bliższym wejrzeniu okazuje się etycznym skandalem wynikającym z faktu, że poddani przemocy są nie tylko jej ofiarami, ale stają się jej dobrowolnymi, a nawet niekiedy fanatycznymi wspólnikami. To, dodajmy na okoliczność naszej sesji ${ }^{4}$, czyni go bliskim autorowi Rozprawy o dobrowolnej niewoli, choć trzeba tu zaznaczyć, że Miłosz, wprawdzie czytelnik Montaigne'a, traktatu przyjaciela autora Prób, pana Étienne'a de La Boétie, raczej nie czytał. Nie ma na to żadnych poświadczeń. Wszelako kluczowy wątek podejmowany przez obu jest wspólny: obaj przenoszą ciężar uwagi z oprawców na ofiary. La Boétie jest renesansowym humanista, kimś, kto stoi na gruncie prawa naturalnego. Zastanawia go tajemnica czynna w zniewoleniu: skandal kondycji człowieka poddanego tyranii, jej nierozum sprzeczny z porządkiem Natury5. Miłosz jest XX-wiecznym intelektualistą, którego rozpoznanie ludzkiej kondycji wpisuje się w pomarksowskie „co było solidne i stałe, rozpływa się w powietrzu"6. Wydaje się, że jego fascynacja ruchem

4 W skróconej wersji tekst ten został przedstawiony na polsko-francuskiej koferencji „La servitude volontaire - dobrowolna niewola", IFIS PAN, 21 czerwca 2017.

5 „Wszelako, wielki Boże, czymże to jest?! Jak nazwać to nieszczęście? Czym jest ta wada, okropna ułomność? [...] Jakąż potworną przywarą jest więc ta, która nie zasługuje nawet na nazwę tchórzostwa, na którą niepodobna znaleźć stosownie ohydnego miana, którą potępia natura i której sam język odmawia imienia?" (s. 8-9), É. de La Boétie Rozprawa o dobrowolnej niewoli, przeł. K. Matuszewski, Stowarzyszenie Inicjatyw Wydawniczych, Katowice 2008, s. 8-9.

6 K. Marks, F. Engels, Manifest komunistyczny, tłum. niezn. autora, Książka i Wiedza, Warszawa 1962 , s. 5 . Jest to parafraza polskiego tłumaczenia, redakcja spopularyzowana w dzisiejszym naszym dyskursie, zwłaszcza po ukazaniu się tłumaczenia książki Marshalla Bermana, pod tym 
jako naczelną zasadą bytu leży u podstaw rozważań, w których zastanawia go „tajemnica powodzenia Nowej Wiary, jej wielki urok dla intelektualistów” (s. 105). Przy tej okazji stara się rozwikłać sprzeczność rozpoznania, że jesteśmy równie stworzeni do wolności, jak i do niewoli, a przejście między pragnieniem wolności a dobrowolną zgodą na jej utratę jest afektywnie bardzo płynne. Zastanawia go niejasne wspólnictwo raz negatywnie, innym znowu razem pozytywnie doświadczanych emocji, jakie rodzi sytuacja zniewolenia. Według La Boétie - niewola korumpuje. Miłosz sądzi nie inaczej, ale w odróżnieniu od La Boétie, zwraca uwagę na pozytywność samozniewolenia. Rezygnacja z wolności według niego powodowana jest także czymś więcej, niż tylko chęcią uśmierzenia lęku "przed myśleniem na własny rachunek" (s. 20). I czymś więcej niż chęcią uzyskania libidalnej gratyfikacji, przyjemności płynącej ze współudzialu w egzekwowaniu przemocy i pozycjonowania się w hierachii podległości. Jak pamiętamy, obie te motywacje to loci communi klasycznej książki Ericha Fromma z 1941 roku. Myślenie Miłosza kieruje się w inną stronę. „Kto przeto uważa za rzecz niezbędną zabezpieczyć się w swym nowym księstwie przed wrogami, zyskiwać sobie przyjaciół, zwyciężać siłą lub zdradą, [musi - przyp. M.Z.] wzbudzać zarówno miłość, jak strach u ludzi" - pisał w swoim traktacie Machiavelli?. W rozumowaniu Miłosza pojawia się dialektyka czyniąca zarówno to, co negatywne, jak i to, co pozytywne - zarówno strach, jak i i miłość, siłami konstytutywnymi w regulowaniu wyborów istot ludzkich. Dla La Boétie motorem dobrowolnego zniewolenia pozostaje bałwochwalstwo, uwielbienie tyrana, ,Jednego,, jak go nazywa. Jest on gwarantem, jak później rozwinie to Hobbes, bezpieczeństwa i społecznego pokoju, redukcji napięć w ekonomii rywalizacji wszystkich ze wszystkimi. Fascynacja i oczarowanie imieniem „Jednego", na którą pomstuje La Boétie (s. 8), to w interpretacji, jaką podsunąć może psychoanaliza, spektakl ojcowskiego autorytetu, Freudowskiego „imienia Ojca”, Lacanowskiego Prawa. Pełni ono funkcję totemu i tabu zarazem, idealnego „ja”, figury, która,

właśnie tytułem. U Miłosza znajdujemy echo słynnego zdania marksowskiego, kiedy pisze o chorobie, na jaką cierpią intelektualiści Zachodu: „Ludzie zachodni, a zwłaszcza intelektualiści tamtejsi, cierpią na szczególny rodzaj taedium vitae; ich emocjonalne i umysłowe życie jest zbyt rozproszone; na próżno próbują ująć tę rzekę rozlewającą się szeroko po żwirach i jałowiznach w jedno obmurowane koryto. Albo, używając innego porównania, wszystko, co myślą i czują, ulatnia się jak para w niezmierzony przestwór [wyróż. - M.Z.]. Wolność jest dla nich ciężarem. Żadne wnioski, do których dochodzą, nie są obowiązujące: może być tak, ale może być też i inaczej. Stąd stała malaise" (s. 104).

7 N. Machiavelli Ksiq̨żę, przeł. Cz. Nanke, PIW, Warszawa 1984, s. 57. 
akurat zdaniem La Boétie, sprawuje tę władzę w sposób tyrański i staje się raczej figurą Ojca primordialnego, ,ja idealnego", omnipotentnego autorytetu. Kimś takim u Milosza okazuje się pisany wielką literą „On”, pojawiający się w pewnej chwili na kartach Zniewolonego umystu jako przedmiot miłosno-nienawistnej adoracji zawsze nie dość zdyscyplinowanych i świadomych poddanych, obywateli totalitarnego państwa, jakim jest Rosja Stalina ${ }^{8}$. „Imię Jednego", omnipotentnego choć skrywającego w sobie ambiwalencję - ale czy nie na tym polega koncept heglowskiej Całości i czy nie na nim pasożytuje dialektyka materalizmu historycznego, czyli jak ją charakteryzuje Miłosz, omnipotentna "Metoda Diamatu"? - imię to jest zarazem metonimią mesjańskiej Jedności, spersonifikowaną i na razie, owszem - choć to myśl bluźniercza - niedoskonałą historyczną inkarnacją przywódcy i arcykapłana wzniosłej wizji społecznej - metonimią marzenia o nas samych jako drobinach szczęśliwej, bo wolnej i sprawiedliwej, ludzkiej wspólnoty. Staje się więc tym samym - na mocy przepływów energii libidalnej - czymś przynależnym do pleromy, ontologicznej pełni ${ }^{9}$. Jest też figurą miłosnej pełni, w której zaleczone zostaje uczucie ssącej pustki, na jaką skazuje nas narcystyczny ideał autokreacji - egoistyczne, ciemne i zaborcze pragnienie własnej doskonałości, autonomii i niepowtarzalności skazujące jednostkę na udrękę. Ta właściwość Nowej Wiary, czyniąca z owego marzenia arche i oferująca

8 Nawet perspektywa dysydenta, jakim jest Miłosz, musi to uwzględnić, choć projektuje on chyba nazbyt silnie własne przekonania na imaginowanych obywateli nowego rosyjskiego imperium: „[obywatel] nienawidzi [...] Jego [Przywódcy - M.Z.] całym sercem, czyniąc Go odpowiedzialnym za straszliwy los narodu rosyjskiego i za nienawiść, jaką naród rosyjski budzi u innych narodów. Nie jest jednak pewien, czy On nie jest potrzebny. Być może, w wyjątkowych okresach, jakim jest okres obecny, pojawienie się przebiegłego tyrana należy uważać za objaw pożądany. Masowe czystki, w których zginęło tylu dobrych komunistów, obniżenie stopy życiowej obywateli, sprowadzenie artystów i uczonych do roli potakujących służalców, eksterminacja całych grup narodowościowych - któż, kto nie byłby taki jak On, odważyłby się na podobne czyny? A jednak Rosja oparła się Hitlerowi. Dzieło rewolucji nie uległo sile uderzającej z zewnątrz. W tym świetle Jego czyny nabierają cech mądrej skuteczności i są usprawiedliwione, być może przez wyjątkową sytuację historyczną. Czy gdyby On nie zastosował wyjątkowego terroru w roku 1937, nie znalazłoby się więcej ludzi chętnych pomagać Hitlerowi niż się znalazło? [...] Jest On ohydną plamą na jasnej Nowej Wierze, ale plamą, którą dzisiaj jeszcze należy tolerować, a nawet należy Go popierać" (s. 87).

9 To znakomicie ilustrują wiersze na cześć Stalina. W wierszu Adama Ważyka Rzeka „mądrość Stalina” jest kosmiczną siłą, nieledwie życiodajną pleromą: „przetacza wody", , wysiewa pszenicę", "zalesia stepy”, ",stawia ogrody” etc. W wierszu Seweryna Pollaka On w Partii żyje czytamy: "Gdzie tu znaleźć właściwe słowo / Które by w sobie zamknęło / Ludzką miłość wielomilionową / Jego troskę i Jego dzieło". Oczywiście, tym słowem może być tylko imię Jego - Stalina. 
zdesperowanym wizję nowego człowieka, człowieka integralnego, staje się dla Miłosza najważniejsza.

Poza zwyczajnym strachem, poza chęcią uchronienia się przed nędzą i fizycznym zniszczeniem działa pragnienie wewnętrznej harmonii i szczęścia. [...] Cokolwiek się powie, Nowa Wiara daje ogromne możliwości czynnego, ruchliwego życia. [...] Jest to świeca, dookoła której krąży on jak ćma, aby wreszcie rzucić się w płomień i z trzaskiem łamiących się skrzydeł dokonać całopalenia na chwałę ludzkości. Pragnienia tego nie wolno lekceważyć. Krew płynęła obficie w Europie w czasie wojen religijnych i kto dzisiaj wstępuje na drogę Nowej Wiary, spłaca dług tej europejskiej tradycji. Sprawa jest dużo poważniejsza niż sprawa przemocy. (s. 26)

Nie przypadkiem słowo „miłość” pojawia się na kartach książki Miłosza równie często jak słowo „strach" (choć to ostatnie jednak częściej).

W rezygnacji z indywidualnej wolności argumenty są mniej ważne niż uczucia i Miłosz jako autor swojej książki ma tego świadomość: „Spróbuję sięgnąć do tych wielkich pragnień i mówić o nich, jakby naprawdę można było analizować to, co jest ciepłą krwią i samym ciałem człowieka. Gdybym chciał opisywać powody, dla których ktoś staje się rewolucjonistą, oczywiście nie potrafiłbym być ani dostatecznie wymowny, ani dostatecznie wstrzemięźliwy" (s. 27) - pisze. I konsekwentnie podąża dalej tym afektywnym tropem. Podkreśla ważność unionistycznego pragnienia „wyalienowanych" intelektualistów, „wielkiego pragnienia bycia w masie” (s. 28), doświadczenia „zbiorowego ciepła” (s. 28). Ale i znaczenie poczucia przynależności rodzącej się z odwołania się do wyższych uczuć, jakie rodziła perspektywa stawania się częścią wielkiego zbiorowego projektu umysłowego. Zamiast zgiełku idei i ćwiczenia się w sceptycyzmie otwierającym furtkę w zimne piekło alienacji,

przychodzi j e d e n system, jeden język pojęć. Woźny i windziarz w domu wydawniczym czytają tych samych klasyków marksizmu co dyrektor firmy i pisarze przynoszący swoje rękopisy; robotnik i badacz historii mogą się odtąd porozumieć. Oczywiście różnica poziomu umysłowego, jaka istnieje pomiędzy nimi, nie jest mniejsza od tej, jaka dzieliła w wiekach średnich doktora teologii i wiejskiego kowala. Ale podstawy są wspólne. Wielka schizma została obalona. System materializmu dialektycznego połączył wszystkich i filozofia (to jest dialektyka) uzyskała znowu wpływ na życie, a traktować ją zaczęto tak poważnie, jak traktuje 
się tylko wiedzę i umiejętność, od znajomości której zależy chleb i mleko dla dzieci, własna pomyślność i bezpieczeństwo. Intelektualista znów stał się użyteczny. (s. 29)

Jak napisał Milosz, temu „poczuciu przywrócenia” towarzyszyła wielka nadzieja metafizyczna likwidująca "ssanie absurdu"w świadomości ludzi, co wyszli cało, choć poranieni z wojny, która zdawała się całopaleniem formacji historycznej, jaka ich zrodziła; z wojny, która dla umysłów europejskich okazała się wielkim rite de passage: przejściem przez „doświadczenia, które uczą o względności ich sądów i myślowych nałogów” (s. 34). Po raz kolejny więc triumfuje zwycięska zasada ruchu. Tyle że owa metafizyczna nadzieja była wołaniem, którego echo wracało jako Schadefreude a nawet wracało jako „życzenie śmierci":

Niech powstanie nowy człowiek, który nie ulega, ale przekształca świat i myśli w skali całego globu i sam stwarza formację historyczną zamiast być jej niewolnikiem. Tylko tak absurdalność jego fizjologicznego trwania może być odkupiona. Trzeba go zmusić siłą, przez cierpienie, do zrozumienia. [...] Jeżeli intelektualista zna mękę myśli, nie należy tej męki oszczędzać innym, tym którzy dotychczas rechotali, pili, żarli, opowiadali głupie dowcipy i w tym widzieli piękno życia. Intelektualista mruży z rozkoszy oczy przypatrując się, jak burżuazja - a również burżuazyjność w ludziach - jest dręczona. Jest to sowita nagroda za poniżenie, jakie czuł, kiedy musiał być jednym z nich i kiedy zdawało się, że nie ma wyjścia z tego kręgu narodzin i śmierci. Wstydliwe rumieńczyki inteligentów nigdy nie nawykłych do ostrego, surowego myślenia, nagle złapanych w potrzask, na przykład zagnanych na akademię w rocznicę rewolucji, akademię, która jest im nienawistna - dają mu chwile upajające. Chłopi zakopujący uciułane złote monety i słuchający zagranicznego radia w nadziei, że wojna uratuje ich od wstąpienia do kołchozów, na pewno nie mają w nim sojusznika. A przecież jest czuły i dobry - jest przyjacielem człowieka, ale nie człowieka takiego, jaki jest. Takiego, jaki powinien być. Nie można go jednak porównywać ze średniowiecznym inkwizytorem. Tamten torturując ciało wierzył, że pracuje nad zbawieniem indywidualnej duszy. Ten pracuje nad zbawieniem ludzkiego gatunku. (s. 31)

Jak zatem widać na tym portrecie, nie tylko miłość i solidarność z rodzajem ludzkim napędzała ekonomię libidalną zgłaszających akces. Zaznacza się 
tu obecność czynnej w tej ekonomii nadwyżki rozkoszy, czegoś, co Lacan określał mianem plus-de-jouir, która niejednoznacznie angażowała rozkosz (jouissance) uczestniczących w grze podmiotów. Z jednej strony ich postępowanie napędzała rozkosz, którą wzbudzała obietnica nadchodzącej ery szczęśliwej ludzkości, rozkosz jako pogoń za niedającym się wyraźnie usymbolizować mirażem (obiektem małe a). $\mathrm{Z}$ drugiej czynna w tym była również ciemna rozkosz jako produkt gier fantazji o zemście na ludzkości nieufilozoficznionej, a powstałe na tym tle poczucie winy znajdowało rozładowanie w transpasywnie przeżywanej realizacji dziejowej sprawiedliwości. Transpasywnie, bo jej egzekutorami byli jednak ciągle jacyś „oni”, „inni”, realizujący ową sprawiedliwość w sposób niedoskonały i nie bez wypaczeń, co niebawem, po Październiku '56, przyznano. Zarówno pierwsza, jak i druga (jako że odsyłały do przyszłości) rozgrzeszały z teraźniejszych uczynków. Psychoanaliza uczy, że jesteśmy odpowiedzialni za naszą jouissance, choć nie w takim samym stopniu jak za swoje czyny. W lacanowskiej wykładni to właśnie próby odczytywania i artykułowania pragnienia Innego pełnią kluczową rolę w radzeniu sobie podmiotu z jego jouissance, nad którym nie można w pełni zapanować i które pozostaje czymś nieosiągalnym. Pragnienie jest obroną przeciwko jouissance wykraczającym poza granice tego, co Freud nazwał „zasadą przyjemności”. Symptom szyfruje nieświadome pragnienie. Jak utrzymują lacaniści, w ekonomii libidalnej na korzyść podmiotu pracuje tego rodzaju symptom, który pozwala raczej utrzymywać pragnienie w niepewności, aniżeli taki, który skazuje podmiot na nieustanne krążenie wokół obiektu małe $a^{10}$.

Najważniejszy więc okazuje się związek między utraconą jouissance i pragnieniem „przekreślonego" (bo ciągle pozostającego enigmą) Innego, skądinąd uwikłanego w przygody własnej jouissance. Ten jego enigmatyczny charakter najlepiej artykułuje się w odwilżowym odczycie Leszka Kołakowskiego Czym jest socjalizm?, który całą serię negatywnych i niesatysfakcjonujących definicji zamyka wyznaniem: „Socjalizm jest to ustrój, który... eh, co tu dużo mówić! Socjalizm to jest naprawdę dobra rzecz"11. Ów związek spełnia się w obiekcie małe a, przyczynie-powodzie zarówno pragnienia, jak i plus-de-jouir - nadmiaru rozkoszy. Podmiot lokuje się jako przyczyna pragnienia Innego (domaga się miłości Innego, stale przy tym cierpiąc, że na nią nie zasługuje), ale i deklaruje

10 Por. O. Hewitson What Does Lacan Say About... Jouissance?, LacanOnline.com, http://www.lacanonline.com/index/2015/07/what-does-lacan-say-about-jouissance, 3.07.2017.

11 L. Kołakowski Czym jest socjalizm (1956), w: tegoż Pochwała niekonsekwencji. Pisma rozproszone z lat 1955-1968, Wydawnictwo Puls, Londyn 1989, s. 113. 
się jako czynny element tego miłosnego kontraktu. Również musi przestać fiksować się na swojej nadwyżce rozkoszy redukującej domniemywaną utratę rozkoszy Innego (uchybienia wobec niego, zadane mu krzywdy, zdrady i niesprawiedliwości mu wyrządzone), budując przestrzeń, w której pojawią się możliwości innego sposobu zapewnienia owej rozkoszy ${ }^{12}$. Według Lacana podmiot rozwiązuje problem swego jouissance w dyskursie i poprzez dyskurs. To on stanowi pole, na którym rozgrywają się dramaty jouissance: wzloty i upadki, uzyskiwane gratyfikacje i dokonywane rekompensaty. Pomieszczone w książce ludzkie portrety Alfy, Bety, Gammy i Delty można czytać jako charakterystyki (nie)radzenia sobie na tym polu. Alfa (prototypem postaci jest, jak wiemy, Jerzy Andrzejewski) nazwany "moralistą” jest kimś, kto jest zakładnikiem swojej „potrzeby czystości”:

Im bardziej martwił się swoim prywatnym, nieuporządkowanym życiem, [to można odczytać jako zaowalowaną aluzję do homoseksualizmu Andrzejewskiego - M.Z.] tym bardziej cenił czynność okupującą, jaką było dla niego pisanie, i tym bardziej nadawał jej wagę uroczystego obrządku. $(\mathrm{s.} 108)^{13}$

Zaangażowanie to „sublimacja samego Alfy, jego drugie «ja», na które przerzucał wszystkie swoje nadzieje" (s. 108), na czym cynicznie żerowali ideolodzy „Nowej Wiary”.

Beta [Tadeusz Borowski] przedstawiony jest jako „nieszczęśliwy kochanek”, oczywiście nieszczęśliwy kochanek świata. Komunizm oferował odmieniony konterfekt obiektu zawiedzionego uczucia, ale czynny w ekonomii uczuć Bety splot miłości i nienawiści wywiódł go poza pole dyskursu (Betę zżerał lęk, że skończył się jako pisarz) i kulminował w dążeniu do samounicestwienia:

Uprościć, obedrzeć ze złudzeń, przedstawić wszystko nago - ta dążność występowała w nim stale. Jednakże idąc coraz dalej ku nagości świata dochodzi się do punktu, w którym intelekt nie ma już nic do powiedzenia

Por. D. Rabinovich What is a Lacanian clinic?, w: The Cambridge Companion to Lacan, ed. by J.-M. Rabaté, Cambridge University Press, Cambridge 2003, S. 220.

13 „Psychoanaliza dostarcza tu jeszcze jednego pola poszukiwań stawiając intrygujące pytanie: w jakim sensie można mówić o sublimacji jouissance?" - zauważa Jean-Michel Rabaté w książce Jacques Lacan. Psychoanalysis and the Subject of Literature, Palgrave, London 2001, s. 23. 
- słowo zmienia się w okrzyk bojowy i jest już tylko niedoskonałym zastępstwem czynu. To, co ono oznacza, lepiej wyraziłaby zaciśnięta pięść. Beta rzeczywiście sam doszedł do stadium, kiedy słowo już nie wystarcza i dlatego nie mógł zadowolić się opowiadaniami czy powieściami, które bądź co bądź trwają w czasie, nie mogą być tylko krzykiem. (s. 159)

Tak przedstawiony przypadek Bety stanowi poniekąd ilustrację niszczycielskiej jouissance, która nietamowana w polu pragnienia i pozbawiona mediacji w dyskursie, zmierza do anihilacji podmiotu.

Gamma [Jerzy Putrament], czyli „niewolnik dziejów”, to przykład na to, jak w przypadku fiaska dyskursu pożądanego, wybór całkiem nowego jego terytorium może stanowić rekompensatę za gdzie indziej odniesione porażki i udręki tłumionej zawiści. Chęcią rekompensaty za doznane porażki poetyckie tłumaczy Miłosz akces Putramenta i jego rozlubowanie się w grach personalnych związanych ze sprawowaniem władzy:

Myślę, że pisząc swoje wiersze pozbawione namiętności, czuł sięźle. [...] Nie był zdolny przeżywać upojeń pisarza ani upojeń procesu twórczego, ani upojeń nasyconej ambicji. (s. 175)

Strategię Delty [Konstantego Ildefonsa Gałczyńskiego], któremu przypadło miano „trubadura”, można zakwalifikować jako cynizm profesjonalisty: całkowite skomformizowanie języka, doskonale plastycznego w zależności od politycznych okoliczności, choć rzekomo pozostającego jedynie w służbie własnego talentu. Ta strategia zapewnia jednak pozorne korzyści. W istocie oznacza rezygnację z własnego dyskursu i tym samym niewydolność prywatnego fantazmatu chroniącego podmiot przed jouissance Innego.

Strategie indywidualne były zatem różne, jednak fantazja o komunizmie jako Innym, tu pojętym jako scena życia w przyszłym sprawiedliwym państwie i szczęśliwym społeczeństwie, dla ludzi zmuszonych do tego, by żyć w społeczeństwie, w którym rządził „strach wszystkich przed wszystkimi” (s. 68) była mitem kompensacyjnym. Dla tych, którzy nie byli wcale przekonani o rychłym nadejściu nowej ery bądź też pozostawali przekonani nie do końca, a w dodatku czuli obrzydzenie do pisania donosów (upokarzającej formy symbolizacji ciemnej jouissance), pozostawał jeszcze jeden atrakcyjny sposób instalowania się w dobrowolnej niewoli. Miłosz poświęca mu cały rozdział swojej książki. Tym sposobem jest „Ketman”, czyli praktykowanie reservatio mentalis. Jak pisze sam Miłosz, Ketman to pojęcie zapożyczone 
z książki XIX-wiecznego francuskiego podróżnika Arthura de Gobineau, autora Les religions et les philosophies dans l'Asie centrale, w której opisuje on zjawisko kamuflowania własnych przekonań. Człowiek, uprawiając Ketman, mówi to, co chce usłyszeć władza, a nie to, co naprawdę myśli. Żyje co prawda w upokarzającym, nieledwie schizofrenicznym rozdwojeniu, ale wewnętrznie zachowuje ciągle niezależność i wolność wynikającą z przekonania, że jego posłuszeństwo płynie z jego własnej woli. Uważa skrycie, że zyskuje coś jeszcze:

Ketman napełnia dumą tego, kto go praktykuje. Wierzący dzięki temu osiąga stan trwałej wyższości nad tym, którego oszukał, chociażby ten ostatni był ministrem czy potężnym królem (s. 81)

- powiada Miłosz za Gobineau. To nie tylko rekompensata, gdyż owa postawa oferuje coś więcej niż tylko symboliczną gratyfikację, oferuje właśnie jeszcze wspomniany już naddatek przyjemności, jaki stanowi uchylające się od symbolizacji jouissance:

Wewnętrznie uśmiechać się, a na zewnątrz okazywać uroczystą żarliwość; nienawidzić, a objawiać oznaki miłości; wiedzieć, a udawać niewiedzę; tak wyprowadzając w pole przeciwnika (który również nas wyprowadza w pole) zaczyna się cenić ponad wszystko własną przebiegłość. Sukces w grze staje się źródłem zadowolenia. Równocześnie to, co w nas jest chronione przed oczami niepowołanych, nabiera dla nas szczególnego waloru, gdyż nie jest nigdy wyraźnie formułowane, a co nie jest formułowane w słowach, posiada irracjonalny urok c zy s to u c zu ci owej jakóści [podkr. - M.Z.]. Człowiek chroni się w wewnętrzne sanktuarium, które jest tym piękniejsze, im większą cenę trzeba zapłacić, aby innym zabronić doń dostępu. (s. 8o)

Ten rodzaj satysfakcji zdaniem Miłosza staje się nałogiem:

Uprawiający Ketman cierpi z powodu przeszkody, na jaką natrafia, ale gdyby przeszkoda została nagle usunięta, znalazłby się w pustce, kto wie czy nie o wiele bardziej przykrej. Wewnętrzny bunt jest nieraz potrzebny dla zdrowia i bywa szczególną odmianą szczęścia. To, co może być powiedziane, bywa o wiele mniej interesujące niż emocjonalna magia obrony własnego sanktuarium. Zdaje się, że dla większości 
ludzi konieczność życia w ciągłym napięciu i czujności jest torturą, ale wielu intelektualistom sprawia to równocześnie masochistyczną przyjemność. (s. 105)

Trzeba tu podkreślić, że zdaniem Miłosza to właśnie Ketman jest najgorszą formą samozniewolenia: ,jest dobrodziejstwem: pielęgnuje marzenie [o niedościgłym ideale - M.Z.]. Człowiek uczy się kochać wzniesione dookoła niego zagrody" (s. 105). Tak dzieje się dlatego, że miejsce w wytyczonych przemocą granicach zamienia w miejsce sekretnego azylu. Poddany dokonuje transgresji: afirmuje obcy porządek, ale jednocześnie go narusza. Chroni się w świat swoich fantazji, ale instalując się w nim, zarazem utwierdza oficjalny porządek. Ketman jest szkodliwą formą samoobrony o tyle, że pasożytuje na pozytywności dokonywanych wyborów: ci, którzy go uprawiają, ignorują obecność przymusu i negatywnych ograniczeń ze strony władzy, przechodzą więc do porządku nad tym, że ich wolność rozumiana jako „wolność od" (wolność negatywna) pozostaje fikcją. Stwarzają sobie natomiast fałszywą w tej sytuacji namiastkę wolności pozytywnej (iluzję „wolności do”). Fałszywą, bowiem ich wolność do przebywania w „wewnętrznym sanktuarium” (jak Miłosz nazywa przestrzeń przemyślnie skonstruowanego azylu) sugeruje istnienie jakiegoś elementu pozytywnego, którego w rzeczywistości brak, jeśli nie są spełnione negatywne warunki jego realizacji, tzn. jeśli chroniący się do mentalnego sanktuarium nie jest wolny w swoim działaniu od ingerencji innych w tym wszystkim, co dotyczy jego wyborów w świecie rzeczywistym. To w istocie wolność w więzieniu własnego umysłu produkującego fantazmaty wolności ${ }^{14}$.

Autor Zniewolonego umystu dopowiada:

Kto wie czy nie w braku wewnętrznego o ś r o d k a w człowieku nie leży tajemnica powodzenia Nowej Wiary, jej wielki urok dla intelektualistów. Nowa Wiara, poddając człowieka ciśnieniu, stwarza ośrodek, a w każdym razie stwarza w nim poczucie, że ten ośrodek istnieje. Strach przed wolnością nie jest niczym innym niż Strachem przed pustką. ,W człowieku nie ma nic - powiedział mi mój przyjaciel-dialektyk - z siebie samego nic nie wydobędziesz, bo tam nic nie ma. Nie możesz odejść od ludzi i na pustyni pisać. Pamiętaj, że człowiek jest funkcją społecznych sił. Kto zechce być sam, zniszczeje". (s. 71) 
Dzisiejszego czytelnika Miłosza uderza obecność znajomych tropów w tym rozumowaniu. Czym jest ów „wewnętrzny ośrodek”, jeśli nie obiektem małe a, niedającym się usymbolizować jądrem, wobec którego człowiek organizuje własne pragnienie? I czym jest zdanie „w człowieku nie ma nic" i następująca po nim konstatacja, że „człowiek jest funkcją społecznych sił", jeśli nie stwierdzeniem, że podmiot jest jedynie pragnieniem Innego?

Miłosz jednak nie jest lacanistą. Dlatego za wszelką cenę stara się wydostać z matni znaczących wiecznie ześlizgujących się z owego „czegoś”. Miłosz chce pozostać przy założeniu,że istnieje raczej coś niż nic, jakkolwiek trudne byłoby do nazwania. Dlatego „przyjacielowi-dialektykowi” odpowiada:

To jest pewnie słuszne. Ale wątpię, czy może to być uznane za coś więcej niż prawo naszych czasów. Gdyby człowiek czuł, że w nim nie ma n i c, Dante nie mógłby napisać Boskiej komedii, Montaigne swoich Prób, a Chardin namalować jednej nawet martwej natury. Uznając, że nic ma w nim n i c, akceptuje dzisiaj cośkolwiek - choćby wiedział, że to cośkolwiek jest złe - byleby znaleźć się razem z innymi i nie być samemu. I dopóki tak uważa, postępowaniu jego nie można wiele zarzucić. Lepiej jest hodować rozrośnięty Ketman i poddawać się ciśnieniu i dzięki temu ciśnieniu mieć chwile poczucia, że się jest, niż ryzykować klęskę zaufawszy mądrości minionych wieków, które twierdziły, że człowiek jest istotą boską. (s. 106)

To prawdziwa, ale smutna wiedza, wiedza prowadząca zawsze do przegranej: człowiek jako efekt swego wyalienowania w porządku symbolicznym nigdy nie jest $u$ siebie panem, zawsze pozostaje $\mathrm{w}$ domu niewoli, zawsze zależny od fikcji mniemanego porządku. Stąd desperacka konkluzja Milosza:

A gdyby spróbować żyć bez ciśnienia i bez Ketmanu, wyzwać los, powiedzieć: „Jeżeli przegram, nie będę siebie żałował?”. Jeżeli da się żyć bez narzuconego oporu, jeżeli da się samemu stworzyć własny opór, to nieprawdą jest, że w człowieku nie ma nic. To byłby akt wiary. (s. 106)

Tak, zapewne: „Gdyby Tygrys był mniejszy / Od Królika i lżejszy, / I cokolwiek grzeczniejszy, / A zaś Królik silniejszy / Od Tygrysa i wyższy, / A znów Tygrys był niższy, / I cokolwiek szczuplejszy, / Wtedy tak by nie brykał / Na biednego 
Królika, / Który jednak jest mniejszy..."15. I czy byłby to tylko akt wiary? To może byłaby równie dobrze psychoza.

\section{Abstract}

\section{Marek Zaleski}

THE INSTITUTE OF LITERARY RESEARCH OF THE POLISH ACADEMY OF SCIENCES (WARSAW)

Content in Their Servitude: Once More on Miłosz's The Captive Mind

Zaleski reads Czesław Miłosz's The Captive Mind through Lacanian psychoanalysis. This framework allows him to trace Miłosz's book as a diagnosis once foreshadowed in Étienne de La Boétie's Discourse on Voluntary Servitude.

\section{Keywords}

Czesław Miłosz, Jacques Lacan, Étienne de La Boétie, voluntary servitude

15 Mruczanka z Kubusia Puchatka w przekładzie Ireny Tuwim. 